\title{
Implementation of Local Regulations Concerning Market Charges and Problems in Practice
}

\author{
Harti $^{*}$
}

${ }^{*}$ Government employees

\begin{abstract}
.
This research raises a problem regarding the Retribution for Markets, Wholesale Markets and Shops controlled by the Demak Regency Government in Bintoro Market, Demak Regency.

This research was conducted with a qualitative approach. The research was conducted at the Demak Regency DPRD, Demak Regency Legislation Section, Demak Regency DPKKD Office. Office of the Department of Industry, Trade, Cooperatives, MSMEs, Regional Regional I Pasat UPTD Offices, Demak District Civil Service Police Unit and Bintoro market. Data collection methods used were interviews and documentation. The data analysis method is descriptive and the analysis used is qualitative.

The results showed that the implementation was not going well. This can be seen in the many articles in Regional Regulation Number 2 of 1999 concerning Retribution for Markets, Wholesale Markets and Shops controlled by the Demak Regency Government which are not applied in the field besides that the collection of field contribution rates is not in accordance with the provisions stipulated in Regional Regulation Number 2 years 1999 concerning Retribution for Markets, Wholesale Markets and Shops controlled by the Demak Regency Government. In the implementation of Regional Regulation Number 2 of 1999 concerning Retribution for Markets, Wholesale Markets and Shops which are controlled by the Demak Regency Government, there are supporting and inhibiting factors.

Keywords: Retribution; Market; Wholesale markets and shops
\end{abstract}

\section{Introduction}

In the administration of governance in the regions and improving services to the community and implementing regional development, the regions need adequate sources of revenue. The sources of this regional revenue can come from assistance and donations from the central government as well as revenues from the regions themselves. Various efforts need to be made in order to explore all possible sources of its own finance in accordance with and within the limits of the prevailing laws and regulations.

In accordance with Law Number 32 of 2004 concerning Regional Government. Where in this law the government gives authority to local governments to make regional regulations. This was done because considering that each region has different potentials and interests. In accordance with the above description, the local government in making regional regulations must not 
contradict Pancasila and the 1945 Constitution. Even so, regional regulations made by local governments sometimes cannot be accepted by the community because people consider these rules to be less suitable when applied to them. the area. however, in its development, the Demak Regency regional regulations governing the market are deemed no longer in accordance with the situation, conditions, and the development of an increasingly modern era. In Article 21 paragraph (2) points 1 and 2 letters a to f Regional Regulation Number 2 of 1999 concerning Retribution for Markets, Wholesale Markets and Shops which are controlled by the Demak Regency Government, it explains that the tariff classification for the use of bases is as follows:

1. For animal market levies:

a. Large livestock (cattle, buffalo, and horses) Rp. 2000; per head every time it enters the market

b. Small livestock (goats, sheep) Rp. 500; per head every time it enters the market

c. Poultry (chickens, ducks and other small animals) Rp. 50; per head every time it enters the market

2. For crop retribution:

a. For the dwarf commodity, the amount is Rp. 75; for one sack / koli for one day

b. For the commodity types of grain, bran, cassava, corn, sorghum Rp. 25; for one sack / koli for one day

c. For the commodity types of rice, soybeans, green beans, peanuts Rp. 50; for one sack / koli for one day

d. The amount of one sack / koli in Article 21 paragraph (2) number 2 letters a to $\mathrm{c}$ is calculated as $50 \mathrm{~kg}$

e. For sellers of weighing services / weighers are required to pay a fee of Rp. 500; for one day

f. For merchandise left / deposited in the market area outside market hours, a rental fee of $25 \%$ of the market levy rate for one day is required.

From the description above, it can be concluded that the tariffs stipulated in Article 21 paragraph (2) points 1 and 2 letters a to f Regional Regulation Number 2 of 1999 concerning Retribution for Markets, Wholesale Markets and Shops controlled by the Demak Regency Government are no longer relevant because nominal tariff there is no currency in the present.

Based on the foregoing, as a legal basis for collecting market fees, the Demak Regency Government needs to regulate and re-establish new regional regulations because Regional Regulation Number 2 of 1999 concerning Retribution for Markets, Wholesale Markets and Shops controlled by the Demak Regency Government is not appropriate. with today's developments. From the description above, the researchers are interested in raising a study entitled "Implementation of Regional Regulation Number 2 of 1999 concerning Market Levies, Wholesale Markets and Shops Controlled by the Government of Demak Regency and the Problems in Practice." This research was only conducted specifically in the market. Bintoro, Demak Regency. 
Departing from the description above, the scope of the problem in this study can be formulated as follows: How to Implement Regional Regulation No. 2 of 1999 concerning Retribution for Markets, Wholesale markets and Shops Controlled by the Government of Demak Regency? What are the supporting and inhibiting factors in the implementation of Regional Regulation Number 2 of 1999 concerning Retribution for Markets, Wholesale Markets and Shops which are controlled by the Demak Regency Government in Bintoro Market, Demak Regency? How are the Local Government Efforts in overcoming the obstacles that arise in the implementation of the Demak Regency Regional Regulation No. 2 of 1999 concerning Retribution for Wholesale Markets and Shops Controlled by the Government of Demak Regency?

\section{Research methods}

This research was conducted with a qualitative approach. The research was conducted at the Demak Regency DPRD, Demak Regency Legislation Section, Demak Regency DPKKD Office. Office of the Department of Industry, Trade, Cooperatives, MSMEs, Regional Regional I Pasat UPTD Offices, Demak District Civil Service Police Unit and Bintoro market. Data collection methods used were interviews and documentation. The data analysis method is descriptive and the analysis used is qualitative.

\section{Discussion of Problems}

\subsection{Implementation of Perda No. 2 TH 1999 concerning Retribution for Markets, Wholesale Markets and Shops which are controlled by the Demak Regency Government}

According to various sources the forms of implementation of Regional Regulation No.2 of 1999 concerning Retribution for Markets, Wholesale Markets and Shops are controlled by the Demak Regency Government, namely:

"With the collection of levies on market traders in Demak Regency by authorized officers" 1

"The form of the implementation of Regional Regulation No. 2 of 1999 concerning Retribution for Markets, Wholesale Markets and Shops controlled by the Demak Regency Government is the collection of daily market levies to increase regional cash"2

"In the daily collection of fees carried out by officers of the levy" (Interview with Edi Purwanto, Head of Regional Revenue for Demak Regency, 12 October 2010) and in the form of collecting fees, managing cleanliness, maintaining security "(Interview with Mukhamad Romli, Head of Management Demak Regency Market,

\footnotetext{
${ }^{1}$ Interview with Kusdarmawan, Head of the Program and Development Section of the Legislation Section of the Demak Regency DPRD,

${ }^{2}$ Interview with Ili Carli, Head of the Demak District Laws Subdivision
} 
October 23, 2010).

"In the form of collecting market fees (Interview with Masrukin, Head of Regional Market I Region Demak Regency, 23 October 2010).

"That is by collecting market levies in accordance with applicable regulations". ${ }^{3}$

From the interview above, it can be concluded that the form of implementation of Regional Regulation Number 2 of 1999 concerning Retribution for Markets, Wholesale Markets and Shops which is controlled by the Demak Regency Government is at the time of collection of fees made by reribusi officers. The retribution officer collects fees at Bintoro Market twice, namely from 06.00 (six in the morning) -18.00 (six in the afternoon) and 19.00 (seven in the evening) -5.00 (five in the morning) respectively, the levy rate is IDR 500 and is not determined based on the area of the kiosk or base occupied.

It is an obligation for traders to pay fees, but sometimes there are traders who do not want to pay fees, if there are traders who do not want to pay the government retribution, they do not take firm action, usually the traders are only given a warning by the fee-collecting officer if they don't pay the levy Most of the traders who sell in the Bintoro Market always pay a levy set by the government, only a small proportion of them do not want to pay, this happens because traders think the contribution given by the government is not in accordance with the amount of retribution they pay.

The contribution from the payment of the retribution is that the traders get a place to sell in the Bintoro Market area because at this time the Bintoro Market is in the construction stage so that whenever traders selling in the Bintoro Market area who want to open a kiosk or their bases they first clean the stall or the base because considering the trading location adjacent to the highway.

Observation data states that the procedures for becoming a trader to occupy a kiosk or base at Bintoro Market are:

a. Fill in the blank application for permission to occupy the kiosk or ground, enclosing:

b. 2 (two) copies of the applicant's identity card.

c. 4 (four) copies of the applicant's photo size $3 \times 4$.

d. Pay administrative fees.

e. Pay a kiosk or floor permit fee.

f. Signing a letter of agreement to occupy a kiosk or base.

\subsection{Supporting and inhibiting factors in the implementation of Regional Regulation Number 2 of 1999 concerning Retribution for Markets, Wholesale Markets and Shops which are controlled by the Demak Regency Government.}

The supporting and inhibiting factors of the implementation of Regional Regulation Number 2 of 1999 concerning Retribution for Markets, Wholesale

\footnotetext{
${ }^{3}$ Interview with Dachirin Emsa, Head of Satpol PP Demak Regency
} 
Markets and Shops controlled by the Demak Regency Government can be seen from how it is implemented.

The supporting factors of the implementation of Regional Regulation Number 2 of 1999 concerning Retribution for Markets, Wholesale Markets and Shops which are controlled by the Demak Regency Government from various sources include:

"Institutions related to market charges that are always responsive to problems that arise in the markets of Demak Regency" 4

"The supporting factor is that the Regent of Demak Regency has made a Regent Regulation Number 35 of 2009 in supporting the implementation of Regional Regulation Number 2 of 1999 concerning Retribution for Markets, Wholesale Markets and Shops which are controlled by the Demak Regency Government"5

"The awareness of traders to pay retribution and user fees who carry out their duties properly" 6

"The supporting factors of the implementation of Regional Regulation No. 2 of 1999 concerning Retribution for Markets, Wholesale Markets and Shops which are controlled by the Demak Regency Government are officers and institutions related to market charges who have worked well and their respective main duties and functions".7

"The supporting factor of the implementation of Regional Regulation Number 2 of 1999 concerning Retribution for Markets, Wholesale Markets and Shops controlled by the Demak Regency Government is the establishment of an UPTD that supervises the markets in each area so that the markets in Demak Regency can be directly monitored by the UPTD. in each region "8

"The supporting factor of the implementation of Regional Regulation No. 2 of 1999 concerning Retribution for Markets, Wholesale Markets and Shops which is controlled by the Demak Regency Government is the public awareness that is so great to pay the fees determined by the government" 9

From the results of the interview above, it can be concluded that the supporting factor of the implementation of Regional Regulation Number 2 of 1999 concerning Retribution for Markets, Wholesale Markets and Shops controlled by the Demak Regency Government is the existence of UPTD markets that control the markets in their respective regions so that the markets in Demak Regency and Bintoro Market are included in regional market UPTD 1. UPTD market region 1 is

\footnotetext{
${ }^{4}$ Edi Purwanto, Interview, Head of Regional Revenue Demak

${ }^{5}$ Interview with Kusdarmawan, Head of the Program and Development Division of the Legislation Section of the Demak Regency DPRD

${ }^{6}$ Interview with Ili Carli, Head of the Demak District Laws Subdivision

${ }^{7}$ Interview with Edi Purwanto, Head of Regional Revenue for Demak Regency

${ }^{8}$ Interview with Mukhamad Romli, Head of the Demak Regency Market Management Division

${ }^{9}$ Interview with Dachirin Emsa, Head of Satpol PP of Demak Regency
} 
very useful in the management of Bintoro Market because UPTD market area 1 is directly involved in managing Bintoro Market starting from collecting user fees, managing facilities and infrastructure, collecting data on traders and UPTD Pasar Daerah 1 is also a bridge for traders in Bintoro Market to channel their criticisms and suggestions to the Demak Regency Government.

\subsection{Inhibiting Factors for the Implementation of Regional Regulation Number 2 of 1999 concerning Retribution for Markets, Wholesale Markets and Shops controlled by the Demak Regency Government}

According to various sources the inhibiting factors of the implementation of Regional Regulation Number 2 of 1999 concerning Retribution for Markets, Wholesale Markets and Shops controlled by the Demak Regency Government in Bintoro Market are:

"The factors that become the obstacle are the lack of awareness in paying fees, the lack of assertiveness of the officers in collecting fees, the lack of market crowd, the lack of facilities and infrastructure" 10

"The inhibiting factor is the lack of awareness of traders to pay fees and demands of traders for existing facilities and infrastructure in the markets of Demak Regency" (Interview with Kusdarmawan, Head of Program and Development Division of Legislation Section DPRD Demak Regency, 26 October 2010).

"Lack of socialization is an obstacle to the implementation of Regional Regulation No. 2 of 1999 on Retribution for Markets, Wholesale Markets and Shops controlled by the Demak Level II Regional Government" (Interview with Ili Carli, Head of Sub-Section of Laws of Demak Regency, 21 October 2010).

"In my opinion, the inhibiting factor of the implementation of Regional Regulation Number 2 of 1999 concerning Retribution for Markets, Wholesale Markets and Shops which is controlled by the Demak Regency Government is the lack of socialization to the community because there are still many people who do not know Regional Regulation Number 2 of 1999 concerning Market Levies," Wholesale markets and shops controlled by the Government of Demak Regency "(Interview with Edi Purwanto, Head of Regional Revenue for Demak Regency, 12 January 2011).11

"The inhibiting factor of the implementation of Regional Regulation No. 2 of 1999 concerning Retribution for Markets, Wholesale Markets and Shops controlled by the Demak Regency Government is that there are still many shortages of retribution-pulling personnel, so that the retribution puller is taken from cleaning officers. In addition, there are still many alarming markets. reduce market crowd "(23 October 2010).12

\footnotetext{
${ }^{10}$ Interview with Masrukin, Head of Regional Market Region I, Demak Regency

${ }^{11}$ Interview with Edi Purwanto, Head of Data Collection, Demak District

${ }^{12}$ Interview with Mukhamad Romli, Head of the Demak Regency Market Management

Division
} 
"The people of Demak Regency lack the curiosity of Regional Regulation No. 2 of 1999 regarding Retribution for Markets, Wholesale Markets and Shops which are controlled by the Demak Regency Government".13

From the results of the interview above it can be concluded that the inhibiting factors of the implementation of Regional Regulation Number 2 of 1999 concerning Retribution for Markets, Wholesale Markets and Shops controlled by the Demak Regency Government include:

a. Lack of socialization of Regional Regulation Number 2 of 1999 concerning Retribution for Markets, Wholesale Markets and Shops which are controlled by the Government of Demak Regency.

b. The traders' lack of awareness in paying retribution.

c. There are still many shortages of retribution attractors, so that people who attract retribution

d. Inadequate facilities and infrastructure in the Demak Regency Market.

e. There are still many poor markets in Demak Regency.

\subsection{Efforts made by the government in overcoming the obstacles that arise in the implementation of Regional Regulation Number 2 of 1999 concerning Retribution for Markets, Wholesale Markets and Shops which are controlled by the Demak Regency Government.}

In the implementation of Regional Regulation No.2 of 1999 concerning Retribution for Markets, Wholesale Markets and Shops which are controlled by the Demak Regency Government, there must be obstacles or obstacles, from the explanation above it can be seen that the obstacles or obstacles from the implementation of Regional Regulation No.2 of 1999 regarding Retribution for Markets, Wholesale Markets and Shops controlled by the Demak Regency Government in Bintoro Market, among others:

a. Lack of socialization of Regional Regulation Number 2 of 1999 concerning Retribution for Markets, Wholesale Markets and Shops which are controlled by the Government of Demak Regency.

b. The traders' lack of awareness in paying retribution.

c. There are still many shortages of retribution attractors, so that people who attract retribution

d. Inadequate facilities and infrastructure in the Demak Regency Market.

e. There are still many poor markets in Demak Regency.

According to several sources of efforts that must be made in overcoming obstacles or obstacles that arise from the implementation of Regional Regulation No.2 of 1999 concerning Retribution for Markets, Wholesale Markets and Shops controlled by the Demak Regency Government in Bintoro Market are:

"Gives understanding to every trader who does not want to pay retribution in accordance with the provisions set by the Demak Regency Government. In addition,

${ }^{13}$ Interview with Dachirin Emsa, Head of Satpol PP of Demak Regency 
the government must make a contribution in accordance with the fees paid by the traders"14

"The way to overcome these obstacles is to provide explanations for traders to pay retribution, give direction to user fees to be firm in collecting fees, increase the feeling of comfort and safety to buyers so that they are happy when they are in the market".15

"By providing socialization to the people of Demak Regency from the top to the bottom" 16

"Yes, by providing socialization to the public regarding Regional Regulation Number 2 of 1999 concerning Retribution for Markets, Wholesale Markets and Shops which are controlled by the Government of Demak Regency".17

"By increasing the number of people who attract retribution and renovating damaged markets".18

"The way to overcome this is by socializing the Regional Regulation Number 2 of 1999 concerning Retribution for Markets, Wholesale Markets and Shops which are controlled by the Demak Regency Government" 19 .

From the interviews with various sources above, it can be concluded that the efforts that must be made by the government to overcome the obstacles or obstacles that arise from the implementation of Regional Regulation No.2 of 1999 concerning Retribution for Markets, Wholesale Markets and Shops controlled by the Demak Regency Government in Bintoro Market are :

a. Providing socialization to the people of Demak Regency regarding Regional Regulation Number 2 of 1999 concerning Retribution for Markets, Wholesale Markets and Shops which are controlled by the Demak Regency Government.

b. Adding retribution collection employees and providing direction to retribution employees so that they can carry out their duties properly.

c. Renovating the buildings of Bintoro Market which have suffered damage.

d. Completing existing facilities and infrastructure in Bintoro Market.

The efforts that have been made by the government in overcoming obstacles or obstacles that arise in the implementation of Regional Regulation Number 2 of 1999 concerning Retribution for Markets, Wholesale Markets and Shops controlled by the Demak Regency Government in Bintoro Market include:

a. The issuance of Regent Regulation Number 35 of 2009

b. Provide socialization to market traders if there are new regulations regarding the market.

\footnotetext{
${ }^{14}$ Kusdarwawan, Interview, Head of Sub Division of Development Program, Demak Regency

${ }^{15}$ Interview with Masrukin, Head of Regional Market Region I, Demak Regency

${ }^{16}$ Interview with Ili Carli, Head of the Demak District Laws Subdivision

${ }^{17}$ Interview with Edi Purwanto, Head of Regional Revenue for Demak Regency

${ }^{18}$ Interview with Mukhamad Romli, Head of the Demak Regency Market Management Division

${ }^{19}$ Interview with Dachirin Emsa, Head of Satpol PP of Demak Regency
} 
c. Renovating market buildings, including the buyaran market and the karanganyar market. Meanwhile, Bintoro Market is still in the process of renovating and is still ongoing.

\section{Closing}

Based on the results of research and discussion, the researchers concluded as follows: The implementation of Demak Regency Regional Regulation Number 2 of 1999 concerning Retribution for Markets, Wholesale Markets and Shops controlled by the Demak Regency Government is not in accordance with what has been regulated in the Perda itself. This is because the Demak Regency Government is less firm in dealing with traders who do not want to pay retribution. Supporting factors and inhibiting factors. The supporting factors are the UPTD market region 1 institution that helps Disperindagkop \& UMKM in managing the Bintoro Market and the main factor that is the obstacle to the implementation of Demak Regency Regional Regulation Number 2 of 1999 concerning Retribution for Markets, Wholesale Markets and Shops controlled by the Demak Regency Government, namely and inadequate infrastructure in Bintoro Market, one of which is a market building that is not suitable for selling.

Based on the conclusions of the research results, the researcher provides the following suggestions: The Demak Regency Government needs to comply more with the Perda regarding market management so that market management in Demak Regency can run properly which is made by itself; Community participation is needed in the formation of new regulations which specifically regulate traders who are in the market because they are the ones directly in the field; The need for additional retribution collection officers and taken from honest people; The Demak Regency Government will immediately complete the construction of the Bintoro Market so that traders and buyers at Bintoro Market feel comfortable when they are at Bintoro Market.

\section{Bibliography}

Danuredjo SLS, 1967, Autonomy in Indonesia is Viewed in the Context Sovereignty, Laras, Jakarta

Josef Riwu Kaho, Regional Autonomy in the Unitary State as a Response Against the Aspirations of a Pluralistic Society and the Challenges of Globalization, Entrepreneur No. 04 th XXIX April 2000

Krisna Darumukti, and Umbu Rauta, 2000, Regional Autonomy, Development

Thought and Execution, Citra Aditya Bakti, Bandung.

Mabsyuri R, 1994, Guide to the Main Concepts of Indonesian Income Tax, Volume I

General Description and about who - who is intended to be taxed, Bina rena Pariwara, Jakarta. 
Marbun SF and Moh. Mahfud, 1987, Principles of State Administration Law, Liberty, Yogyakarta.

Riwu Kaho, Josef, 2000, Regional Autonomy in a Unitary State Responsive to the Aspirations of Community Diversity and Challenges Globalization, Entrepreneur No. 04 Th. XXIX 2000.

Saleh Syariff, 1953, Autonomy and Autonomous Regions, Endang, Jakarta.

Satjipto, Raharjo. 1983. Law Enforcement Problems. Bandung: Sinar Baru.

Soerjono, Soekanto. 1983. Factors Affecting Law Enforcement. Jakarta: Rajawali.

Syakrani and Syahriani. 2009. Implementation of Regional Autonomy in a Good Governance Perspective. Jogjakarta: Student Library.

Sincere. S. Meliala, 1991, Taxation in Theory and Practice, Widya Dharma, Bandung. WJ S Poerwadarminto, 1986, General Indonesian Dictionary, Balai Pustaka, Jakarta.

Wajong, J, 1975, Principles and Goals of Local Government, Jakarta.

Widjaya, HAW., 2002, Regional Autonomy and Autonomous Regions, Raja Grafindo Persada, Jakarta. 